\title{
THE INFLUENCE OF INTELLECTUAL INTELLIGENCE AND LEARNING MOTIVATION AGAINST STUDENT'S MATHEMATICS LEARNING OUTCOMES IN REGION 3 KELURAHAN PEGADUNGAN JAKARTA BARAT
}

\author{
Dwi Ningrum Handarini, Karta Sasmita, Ika Lestari \\ Universitas Terbuka (UT) Jakarta Indonesia \\ Email: dwiningrumhandarini82@gmail.com,
}

\begin{abstract}
Abstrak
Penelitian ini bertujuan untuk membuktikan pengaruh kecerdasan intelektual dan motivasi belajar terhadap hasil belajar matematika siswa secara parsial maupun simultan. Defenisi hasil belajar dalam penelitian ini adalah perolehan dari proses belajar siswa sesuai dengan tujuan pengajaran pada ranah kognitif yang meliputi aspek C1 (remember), C2 (understand), dan C3 (applying). Kecerdasan intelektual atau IQ sering disebut sebagai kecerdasan yang mengacu terhadap kemampuan kognitif seseorang, yaitu kemampuan berfikir yang tinggi dalam usaha meningkatkan kemampuan yang dimiliki seorang siswa, kemampuan menalar merencanakan masalah, memahami gagasan, menggunakan bahasa dan belajar. Motivasi belajar adalah dorongan atau kekuatan mental yang mendorong, menggerakkan, dan mengarahkan siswa untuk belajar. Penelitian ini menggunakan pendekatan kuantitatif dengan metode survey. Teknik pengambilan sampelnya menggunakan teknik propotional random sampling. Sampel penelitian ini adalah siswa kelas VI dengan jumlah 92 siswa. Instrumen yang digunakan berupa data tes IQ, angket dan tes. Analisis data menggunakan regresi regresi linear berganda. Hasil penelitian menunjukkan bahwa (1) Kecerdasan intelektual berpengaruh signifikan terhadap hasil belajar matematika siswa, (2) motivasi belajar berpengaruh signifikan terhadap hasil belajar matematika siswa, (3) Kecerdasan intelektual dan motivasi belajar mempunyai pengaruh yang signifikan terhadap hasil belajar matematika siswa. Hasil penelitian ini dapat dijadikan referensi bagi sekolah yang ingin mendapatkan hasil belajar matematika siswa maksimal.
\end{abstract}

Kata Kunci: kecerdasan intelektual; motivasi belajar; hasil belajar matematika

\section{Abstract}

This study aims to prove the influence of intellectual intelligence and learning motivation on students' math learning results partially or simultaneously. Defenisi learning results in this study is the acquisition of the student's learning process in accordance with the objectives of teaching in the cognitive sphere covering aspects of $C 1$ (remember), C2 (understand), and C3 (applying). Intellectual intelligence or $I Q$ is often referred to as intelligence that refers to a person's cognitive abilities, namely high thinking ability in an effort to improve a student's abilities, the ability to reason to plan problems, understand ideas, use language and learn. Learning motivation is a mental drive or strength that encourages, moves, and directs

$\begin{array}{ll}\text { How to cite: } & \text { Handarini. D.N., Karta Sasmita \& Ika Lestari (2021) The Influence Of Intellectual Intelligence And Learning } \\ & \text { Motivation Against Student's Mathematics Learning Outcomes In Region } 3 \text { Kelurahan Pegadungan Jakarta } \\ & \text { Barat. Syntax Literate: Jurnal Ilmiah Indonesia, 6(12). http://dx.doi.org/10.36418/Syntax- } \\ & \text { Literate.v6i12.2715 } \\ \text { E-ISSN: } & \text { 2548-1398 } \\ \text { Published by: } & \text { Ridwan Institute }\end{array}$


students to learn. This research uses quantitative approach with survey method. The sampling technique uses propotional random sampling techniques. The sample of this study was grade 6 students with a total of 92 students. Instruments used in the form of IQ test data, questionnaires and tests. Data analysis using multiple linear regression regression. The results showed that (1) Intellectual intelligence has a significant influence on students' math learning outcomes, (2) learning motivation has a significant influence on students' math learning outcomes, (3) Intellectual intelligence and learning motivation have a significant influence on students' math learning outcomes. The results of this study can be used as a reference for schools that want to get maximum student math learning results.

Keywords: intellectual intelligence; learning motivation; mathematics learning outcomes

Received: 2021-11-20; Accepted: 2021-12-05; Published: 2021-12-20

\section{Pendahuluan}

Pendidikan adalah suatu proses perubahan tingkah laku dalam kehidupan yang berlangsung selama manusia hidup di dunia. (Sadulloh, 2010) menyatakan bahwa manusia memulai pendidikan selama hidup sampai kematian, selama manusia menerima pengaruh dan mengembangkannya. Pendapat tersebut menjelaskan bahwa pendidikan tidak hanya dibangku sekolah akan tetapi melalui lingkungan terutama keluarga dan lingkungan masyarakat.

Hal mendasar yang dapat mempengaruhi kualitas pendidikan salah satunya dapat dilihat melalui bagiamana pelaksanaan proses belajar mengajarnya. Ini berarti berhasil tidaknya pencapaian tujuan pendidikan bergantung kepada proses belajar yang dialami siswa. Seseorang yang telah melalui proses belajar diharapkan akan mengalami perubahan tingkah laku, yang dimaksud perubahan tingkah laku disini dapat berupa pengetahuan setelah melalui tahapan belajar. Seperti yang diungkapkan oleh (Slameto, 2015) bahwa "Belajar ialah suatu proses usaha yang dilakukan seseorang untuk memperoleh suatu perubahan tingkah laku yang baru secara keseluruhan, sebagai hasil pengalamannya sendiri dalam interaksi dengan lingkungannya.

Matematika maerupaka ilmu universal yang mempelajari perkembangan teknologi modern serta mempunyai peranan penting dalam berbagai disiplin ilmu dan memajukan kemampuan berfikir manusia. Agar dapat menguasai dapat menguasai dan menciptakan teknologi pada masa depan, maka diperlukan penguasaan matematika yang kuat sejak usia dini. Hal inilah yang menjadikan matematika sebagai dasar pengembangan ilmu dan teknologi.

Kenyataannya berdasarkan hasil studi PISA Tahun 2018 bahwa peringkat matematika negara Indonesia berada di urutan ke 72 dari 78 negara dengan score matematika sebesar 379, selain itu ketika proses belajar matematika siswa cenderung tidak antusias, kemampuan menguasai materi matematika cenderung lebih rendah dibandingkan dengan pelajaran lainnya, seringkali siswa merasa kesulitan memahami yang diajarkan guru sehingga menganggap matematika adalah pelajaran sulit. 
The Influence of Intellectual Intelligence and Learning Motivation Against Student's Mathematics Learning Outcomes In Region 3 Kelurahan Pegadungan Jakarta Barat

Kebanyakan dari siswa berfikir bahwa matematika adalah pelajaran yang sulit dan rumit. Hal tersebut menyebabkan rendahnya hasil belajar matematika, sehingga masih banyak siswa yang mendapatkan nilai matematika di bawah KKM. Oleh karena itulah peneliti ingin meneliti faktor penyebab rendahnya nilai tersebut, karena jika dibiarkan akan berpengaruh terhadap kualitas pendidikan di sekolah yang juga berdampak pada rendahnya kualitas pendidikan di negara kita.

Salah satu upaya yang digunakan untuk mewujudkan tujuan tersebut adalah meningkatkan hasil belajar siswa. Hasil belajar siswa akan terlihat bagus apabila memiliki kesiapan dalam belajar. Ada beberapa faktor yang dapat mempengaruhi kesiapan dalam belajar salah satunya faktor intelegensi, motivasi, minat, bakat, perhatian, dan kesiapan siswa.

Belajar merupakan kegiatan yang selalu dialami dan dilakukan oleh manusia. Belajar tidak mengenal waktu, usia, maupun gender. Bahkan sejak dalam kandungan seorang bayi itu mulai belajar, dengan belajar manusia bisa mengembangkan potensipotensi yang dibawa sejak lahir. Menurut (Sagala, 2013) "Belajar adalah suatu kegiatan yang dilakukan secara sadar untuk mendapatkan sejumlah hal penting dari pengalaman yang telah dialami”. Defenisi belajar yang disampaikan (Sadiman, 2009) “ Belajar merupakan suatu proses yang terjadi pada diri seseorang yang berlangsung seumur hidupnya sejak ia dilahirkan sampai ia meninggal atau ke liang lahat". Ketika seseorang telah belajar maka yang diinginkan yaitu hasil dari proses belajar tersebut.

Hasil belajar merupakan tujuan yang akan dicapai dari suatu proses kegiatan pembelajaran. Hasil belajar adalah kemampuan-kemampuan yang diperoleh siswa setelah melalui kegiatan belajar. Menurut (Sudjana, 2002) menyatakan bahwa hasil belajar adalah kemampuan yang dimiliki siswa setelah ia menerima pengalaman belajarnya. Sehingga hasil belajar merupakan salah satu ukuran penguasaan yang dimiliki siswa setelah mendapatkan proses pembelajaran. Seperti yang disampaikan oleh (Dimyati, 2013) mengungkapkan bahwa hasil belajar merupakan hasil dari suatu interaksi dan tindak belajar dan tindak mengajar. Hasil belajar merupakan tolak ukur atau patokan yang menentukan tingkat keberhasilan siswa dalam mengetahui dan memahami suatu materi pelajaran dari proses pengalaman belajar terus menerus yang diukur dengan tes dan dinyatakan dalam bentuk nilai atau angka yang berdasarkan kriteria penilaian.

Menurut (Suriasumantri, 2007) menyatakan bahwa" matematika adalah bahasa yang melambangkan serangkaian makna dari pernyataan yang ingin kita sampaikan, lambing-lambang matematika bersifat artificial yang baru mempunyai arti setelah sebuah makna diberikan kepadanya. (Cipta, 2014) menyatakan bahwa matematika adalah simbolis yang fungsi praktisnya untuk mengekspresikan hubungan-hubungan kuantitatif dan kekurangan sehingga fungsi teoritisnya adalah untuk memudahkan berpikir.

Hasil belajar matematika merupakan hasil yang dicapai berupa nilai setelah melakukan proses kegiatan belajar matematika, dimana penelitian ini terfokus pada hasil belajar keliling dan luas lingkaran. 
Intelegensi merupakan salah satu faktor internal yang mempengaruhi prestasi akademik seseorang. Kecerdasan Intelektual (IQ) merupakan interpretasi hasil intelegensi (kecerdasan) ke dalam angka yang dapat menjadi petunjuk mengenai kedudukan tingkat intelegensi seseorang. Alfred Binet dan Theodore Simon (dalam (Azwar, 2008) mendefenisikan bahwa intelegensi sebagai suatu kemampuan yang terdiri dari tiga komponen, yaitu : a) kemampuan dalam mengarahkan pikiran dana tau mengarahkan tindakan, b) kemampuan untuk mengubah arah sebuah tindakan bila tindakan tersebut telah dilaksanakan, c) kemampuan untuk mengeritik diri sendiri.

Menurut (Yani, 2012) mengatakan bahwa kecerdasan intelektual adalah kemampuan untuk memperoleh, memanggil kembali (recall), dan menggunakan pengetahuan untuk memahami konsep-konsep abstrak maupun konkret dan hubungan antara objek dan ide, serta menerapkan pengetahuan secara tepat. Tingkat kecerdasan intelektual manusia dapat kita ukur dengan tes yang bernama tes IQ (Intelegent Quentient). Berkat kecerdasan intelektualnya manusia telah mampu menciptakan teknologi informasi dan transportasi yang menjadikan dunia terasa lebih dekat dan semakin transparan yang menjadikan dunia terasa lebih dekat dan semakin transparan, menciptakan alat-alat teknologi lainnya yang lebih canggih. IQ atay daya tangkap seseorang mulai dapat ditentukan sekitar usia 3 tahun. Daya tangkap ini sangat dipengaruhi oleh faktor keterunan atau gen, IQ atau daya tangkap dianggap tidak akan berubah sampai dewasa, kecuali bila ada sebab tangkap dianggap tidak akan berubah sampai dewasa, kecuali bila ada sebab kemunduran fungsi otak seperti penuaan, kecelakaan karena tidak terjadi perkembangan lagi pada titik tertentu sehingga akan mengalami penurunan kemampuan.

Menurut Aldefer dalam (Nashar, 2004) motivasi belajar adalah kecenderungan siswa dalam melakukan kegiatan belajar yang didorong oleh hasrat untuk mencapau prestasi belajar sebaik mungkin. Motivasi dapat mendorong seseorang untuk berbuat dan bertindak. Motivasi akan menjadi pendorong dan mesin bagi manusia untuk bergerak yang membuat seseorang dapat melakukan sesuatu untuk mencapai tujuannya. Motivasi juga berfungsi sebagai penentu arah perwujudan cita-cita .

(Purwanto, 2017) menyatakan bahwa "tujuan motivasi bagi seorang guru adalah menggerakkan atau memacu para siswanya agar timbul keinginan dan kemauannya untuk meningkatkan prestasi belajarnya sehingga tercapai tujuan pendidikan sesuai dengan yang diharapkan dan ditetapkan dalam kurikulum sekolah". Motivasi merupakan salah satu faktor penting yang mempengaruhi belajar dan hasil belajar siswa, memiliki motivasi kecenderungan untuk mencurahkan segala kemampuannya agar mendapatkan hasil belajar yang optimal sesuai dengan harapannya. Semakin tinggi motivasi yang dimiliki siswa akan mendorong siswa belajar lebih giat lagi dan intensitas belajarnya menjadi semakin meningkat, akan tetapi kuat dan lemahnya motivasi seseorang berbeda, hal tersebut dipengaruhi oleh faktor cita-cita, kemampuan belajar, kondisi siswa, kondisi lingkungan sekolah, unsur-unsur dinamis dalam belajar, dan upaya guru dala membelajarkan siswa. 
Berdasarkan latar belakang masalah yang diuraikan di atas, maka dirumuskan masalah sebagai berikut: "Apakah terdapat pengaruh kecerdasan intelektual, motivasi belajar terhadap hasil belajar matematika siswa?".

Dengan mengacu pada permasalahan, tujuan penelitian ini adalah: " Untuk mengetahui menganalisis pengaruh kecerdasan intelektual, motivasi belajar terhadap hasil belajar matematika siswa SD Negeri di Wilayah 3 Kelurahan Pegadungan Jakarta Barat".

\section{Metode Penelitian}

Jenis penelitian ini menggunakan metode survey dengan pendekatan kuantitatif. Penelitian kuantitatif merupakan metode-metode yang didasarkan pada informasi numerik dan menggunakan analisis-analis statistik yang terdiri dari analisis isi, penelitian survey dan penelitian arsip.

Populasi penelitian ini adalah seluruh siswa SDN Pegadungan 02 Pagi, SDN Pegadungan 04 Pagi, dan SDN Pegadungan 11 Pagi. Sampel dalam penelitian ini adalah propotional random sampling, yaitu menentukan sampel diambil dari perwakilan tiaptiap sekolah yang ada di dalam populasi. Sehingga sampel yang digunakan dari populasi 1.187 siswa yaitu sebanyak 92 siswa.

Untuk menganalisis data dalam penelitian ini digunakan analisis regresi linier berganda. Model ini digunakan untuk mengetahui pengaruh variabel bebas terhadap variabel terikat. Model regresi berganda yang dipakai dalam penelitian ini telah memenuhi syarat asumsi klasik yaitu; 1) uji normalitas tes Kolmogrov-Smirnov; 2) uji multikolinieritas; 3) uji heteroskedastisitas; 4) uji linieritas.

\section{Hasil dan Pembahasan}

\section{A. Hasil Penelitian}

\section{Uji Normalitas}

\section{Tabel 1}

One-Sample Kolmogorov-Smirnov Test

\begin{tabular}{lll}
\hline & $\begin{array}{l}\text { Unstandardized } \\
\text { Residual }\end{array}$ & Kesimpulan \\
\hline kolmogorvre-smirnov Z & .585 & \\
Asymp. Sig. (2-tailed) & .884 & Berdistribusi Normal \\
\hline
\end{tabular}

Data Diolah Menggunakan SPSS 20

Berdasarkan tabel di atas menunjukkan nilai tes statistic Kolmogorov Smirnov $=0,585$ dan nilai $\operatorname{sig}(\mathrm{P}$-value $)=0,884>0,05$ maka data tersebut berdistribusi normal. 


\section{Uji Mulitikolinearitas}

Tabel 2

Hasil Perhitungan Koefisien

\begin{tabular}{llll}
\hline No & Variabel & Tolerance & VIF \\
\hline 1. & Kecerdasan intelektual & .783 & 1,277 \\
2. & Motivasi belajar & .783 & 1,277 \\
\hline \multicolumn{4}{c}{ Dependent Variable: Hasil } \\
\hline
\end{tabular}

Berdasarkan tabel 2 bahwa nilai tolerance $0.783>0,1$ dan nilai VIF $1,277<10$ maka dapat disimpulkan bahwa tidak ada multikolinearitas sehingga analisis regresi dapat dipergunakan dalam penelitian ini.

\section{Uji Heteroskedastisitas}

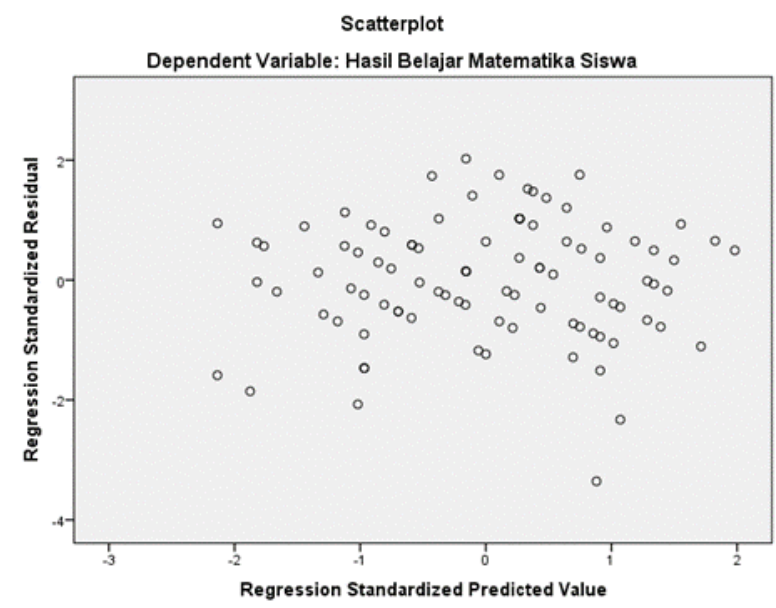

Berdasarkan gambar di atas menunjukkan bahwa titik-titik menyebar secara acak dan tidak membentuk pola tertentu yang jelas serta menyebar di atas maupun di bawah angka 0 pada sumbu Y. Hal ini menunjukkan tidak terjadi heteroskedastisitas pada model regresi tersebut, sehingga dapat dipakai untuk memprediksi variabel hasil belajar natematika berdasarkan kecerdasan intelektual dan motivasi belajar.

\section{Uji Linearitas}

a. Linearitas Garis Regresi Hubungan antara Variabel X1 dengan Variabel

\section{Tabel 3}

\section{ANOVA Table}

\begin{tabular}{lllrrrrr}
\hline & & & \multicolumn{1}{c}{$\begin{array}{c}\text { Sum of } \\
\text { Squares }\end{array}$} & \multicolumn{1}{c}{$\begin{array}{c}\text { Mean } \\
\text { Square }\end{array}$} & \multicolumn{1}{c}{ F } & Sig. \\
\hline Hasil Belajar & Between & (Combined) & 9254.498 & 24 & 385.604 & 2.224 & .006 \\
Matematika Siswa * & Groups & Linearity & 5254.367 & 1 & 5254.367 & 30.305 & .000 \\
Kecerdasan Intelektual & & $\begin{array}{l}\text { Deviation } \\
\text { from Linearity }\end{array}$ & 4000.131 & 23 & 173.919 & 1.003 & .474 \\
& & & & & & \\
\cline { 2 - 8 } & & & 11616.720 & 67 & 173.384 & & \\
\cline { 2 - 9 } & Within Groups & 20871.217 & 91 & & & \\
\hline
\end{tabular}


The Influence of Intellectual Intelligence and Learning Motivation Against Student's Mathematics Learning Outcomes In Region 3 Kelurahan Pegadungan Jakarta Barat

Pada table ANOVA di atas bagian Deviation from Linearity menunjukkan hubungan antara Kecerdasan Intelektual dengan Hasil Belajar Matematika siswa menghasilkan $\mathrm{F}=1,003$ dengan nilai probabilitas (kolom sig) $\mathrm{p}=0,474$. Karena nilai signifikansi $\mathrm{p}=0,474>0,05$ maka dengan demikian $\mathrm{H} 0$ diterima dan $\mathrm{H} 1$ ditolak dan dapat disimpulkan bahwa model regresi bersifat linier.

b. Linearitas Garis Regresi Hubungan antara Variabel X2 dengan Variabel Y

Tabel 4

ANOVA Table

\begin{tabular}{|c|c|c|c|c|c|c|c|}
\hline & & & $\begin{array}{c}\text { Sum of } \\
\text { Squares }\end{array}$ & df & $\begin{array}{c}\text { Mean } \\
\text { Square }\end{array}$ & $\mathbf{F}$ & Sig. \\
\hline \multirow{5}{*}{$\begin{array}{l}\text { Hasil Belajar } \\
\text { Matematika } \\
\text { Siswa * Motivasi } \\
\text { Belajar }\end{array}$} & Between & (Combined) & 15808.517 & 44 & 359.284 & 3.335 & .000 \\
\hline & Groups & Linearity & 9900.075 & 1 & 9900.075 & 91.90 & .000 \\
\hline & & $\begin{array}{l}\text { Deviation } \\
\text { from Linearity }\end{array}$ & 5908.442 & 43 & 137.406 & 1.276 & .20 \\
\hline & Within G & & 5062.700 & 47 & 107.717 & & \\
\hline & Total & & 20871.217 & 91 & & & \\
\hline
\end{tabular}

Pada table ANOVA di atas di bagian Deviation from Linierity menunjukkan hubungan antara Motivasi Belajar dengan Hasil Belajar Matematika siswa menghasilkan nilai $\mathrm{F}=1,276$ dengan nilai probabilitas (kolom sig) $\mathrm{p}=0,207$. Karena nilai signifikansi $\mathrm{p}=0,207>0,05$ maka dengan demikian $\mathrm{H} 0$ diterima dan H1 ditolak dan dapat disimpulkan bahwa model regresi bersifat linier.

\section{Uji Hipotesis Penelitian}

\section{Tabel 5}

Hasil Perhitungan Pengujian Signifikasi Variabel X1 dan X2 Terhadap Y

\begin{tabular}{|c|c|c|c|c|c|c|}
\hline \multicolumn{7}{|c|}{ Coefficients $^{\mathrm{a}}$} \\
\hline & \multirow[b]{2}{*}{ Model } & \multicolumn{2}{|c|}{$\begin{array}{l}\text { Unstandardized } \\
\text { Coefficients }\end{array}$} & \multirow{2}{*}{$\begin{array}{c}\begin{array}{c}\text { Standardized } \\
\text { Coefficients }\end{array} \\
\text { Beta } \\
\end{array}$} & \multirow[b]{2}{*}{$\mathrm{t}$} & \multirow[b]{2}{*}{ Sig. } \\
\hline & & B & Std. Error & & & \\
\hline \multirow[t]{3}{*}{1} & (Constant) & -55.625 & 19.679 & & $\begin{array}{c}- \\
2.827\end{array}$ & .006 \\
\hline & $\begin{array}{c}\text { Kecerdasan } \\
\text { Intelektual }\end{array}$ & .575 & .207 & .231 & 2.772 & .007 \\
\hline & Motivasi Belajar & .585 & .084 & .581 & 6.973 & .000 \\
\hline
\end{tabular}


Berdasarkan tabel 5 menunjukkan bahwa :

a. Nilai sig $=0.007<0,05$ dan thitung $=2,772$, hal ini menunjukkan bahwa H0 ditolak dan $\mathrm{H} 1$ diterima artinya terdapat pengaruh yang signifikan kecerdasan intelektual terhadap hasil belajar matematika.

b. Nilai sig $=0.000<0,05$ dan thitung $=6,973$, hal ini menunjukkan bahwa $\mathrm{HO}$ ditolak dan H1 diterima artinya terdapat pengaruh yang signifikan motivasi belajar terhadap hasil belajar matematika.

\section{Tabel 6}

Hasil Perhitungan Koefisien Korelasi Pengaruh Variabel X1 dan X2 Terhadap Y

\begin{tabular}{llccc}
\hline \multicolumn{5}{c}{ Model Summary } \\
\hline Model & $\mathrm{R}$ & $\mathrm{R}$ Square & $\begin{array}{c}\text { Adjusted R } \\
\text { Square }\end{array}$ & $\begin{array}{l}\text { Std. Error of } \\
\text { the Estimate }\end{array}$ \\
\hline 1 & $.718^{\mathrm{a}}$ & .516 & .505 & 10.652 \\
\hline a. Predictors: (Constant), Motivasi Belajar, Kecerdasan \\
Intelektual
\end{tabular}

Berdasarkan tabel 6 bahwa terdapat pengaruh yang signifikan variabel bebas kecerdasan intelektual (X1) dan motivasi belajar (X2) secara bersama-sama terhadap hasil belajar matematika (Y) sebesar 0,718 sedangkan koefisien determinasinya sebesar 0,516 menunjukkan bahwa besarnya kontribusi antara ke kecerdasan intelektual (X1) dan motivasi belajar (X2) secara bersama-sama terhadap hasil belajar (Y) adalah sebesar 51,6\%, sisanya 48,4\% dipengaruhi oleh faktor lain.

Tabel 7

Rekapitulasi Hasil Perhitungan Persamaan Garis Regresi Pengaruh Variabel X1 dan X2 Terhadap Y

\begin{tabular}{|c|c|c|c|c|c|c|}
\hline \multicolumn{7}{|c|}{ ANOVA $^{a}$} \\
\hline \multicolumn{2}{|l|}{ Model } & $\begin{array}{l}\text { Sum of } \\
\text { Squares }\end{array}$ & df & Mean Square & $\mathrm{F}$ & Sig. \\
\hline \multirow[t]{3}{*}{1} & Regression & 10772.296 & 2 & 5386.148 & 47.467 & $.000^{\mathrm{b}}$ \\
\hline & Residual & 10098.921 & 89 & 113.471 & & \\
\hline & Total & 20871.217 & 91 & & & \\
\hline
\end{tabular}

a. Dependent Variable: Hasil Belajar Matematika Siswa

b. Predictors: (Constant), Motivasi Belajar, Kecerdasan Intelektual

Berdasarkan tabel 7 menunjukkan bahwa nilai $\operatorname{Sig}=0,000<0,05$ dan Fhitung $=47,467$, hal ini menunjukkan bahwa $\mathrm{H} 0$ ditolak dan $\mathrm{H} 1$ diterima. Sehingga hipotesis penelitian dapat diterima, artinya terdapat pengaruh yang signifikan kecerdasan intelektual dan motivasi belajar secara bersama-sama terhadap hasil belajar matematika. 
The Influence of Intellectual Intelligence and Learning Motivation Against Student's

Mathematics Learning Outcomes In Region 3 Kelurahan Pegadungan Jakarta Barat

\section{B. Pembahasan}

\section{A. Pengaruh Kecerdasan Intelektual (X1) terhadap Hasil Belajar Matematika (Y)}

Berdasarkan data kecerdasan data kecedasan intelektual yang diperoleh dari dokumen sekolah dengan skor terendah 88, skor tertinggi 117, skor rerata (mean) 107,08, median 108,00, modus 108 dan simpangan baku 6.090. Nilai sig $=0.006<$ 0,05 dan thitung $=2,802$ dengan kontribusi kecerdasan intelektual terhadap hasil belajar sebesar $11,60 \%$. Sehingga keceradasan intelektual siswa menjadi faktor yang dominan terhadap tercapainya prestasi belajar terutama pada hasil belajar matematika. Hal ini diperkuat penelitian yang dilakukan oleh Zentra Hainul Putra (2015) yang berjudul "Hubungan Intelegensi dengan Hasil Belajar Matematika Siswa Kelas V SD Negeri 68 Pekan Baru” dengan hasil penelitian menunjukkan bahwa terdapat hubungan yang signifikan antara intelegensi dengan hasil belajar matematika ditunjukkan dengan semakin tinggi hasil intelegensi yang diberikan maka akan semakin tinggi hasil belajar matematika.

Sehingga penelitian yang dilakukan sejalan dan sangat relevan terhadap penelitian terdahulu, sehingga dapat disimpulkan bahwa siswa yang memiliki kecerdasan intelektual yang tinggi akan mudah menerima pelajaran dan hasil belajar matematikanya pun akan meningkat begitu pula sebaliknya siswa yang memiliki kecerdasan intelektual rendah maka akan mengalami hambatan dalam menerima pelajaran dan mengakibatkan hasil belajar matematikanya rendah.

\section{B. Pengaruh Motivasi Belajar (X2) terhadap Hasil Belajar Matematika (Y)}

Berdasarkan data motivasi belajar dari kuesioner yang dijawab 92 siswa sebagai responden dapat dihasilkan skor terendah 87 , skor tertinggi 150 , skor rerata (mean) 114,91, median 116,50, modus 127, dan simpangan baku sebesar 15.032. Nilai Sig $=0,000<0,05$ dan thitung $=7,079$ dengan kontribusi motivasi belajar terhadap hasil belajar matematika sebesar 40,03\% sedangkan sisanya dipengaruhi oleh variabel lain.

Penelitian ini diperkuat dengan penelitian terdahulu yang dilakukan oleh Risa Triarisanti dan Pupung Purnawarman (2019) dengan penelitiannya yang berjudul "The Influence of Interest And Motivation On College Students Language And Art Apreciation Learning Outcomes", hasil penelitian menunjukkan bahwa tingginya minat dan motivasi sangat menentukan keberhasilan belajar khususnya pada mata pelajaran apresiasi Bahasa dan seni.

Tujuan dari motivasi belajar yaitu untuk menggerakan atau menggugah seseorang agar timbul keinginan dan kemauannya untuk mencapai sesuatu sehingga dapat memperoleh hasil atau mencapai tujuan tertentu. Motivasi belajar memiliki peran yang sangat tinggi dalam pembelajaran siswa. Sehingga berdasarkan penelitian ini dapat dikatakan bahwa siswa yang memiliki motivasi tinggi akan menghasilkan hasil belajar matematika yang tinggi pula, begitu sebaliknya jika motivasi belajar rendah maka akan menghasilkan hasil belajar matematika rendah. 


\section{Pengaruh Kecerdasan Intelektual (X1) dan Motivasi Belajar (X2) terhadap Hasil Belajar Matematika (Y)}

Berdasarkan deskriptif data setelah dilakukan analisis korelasi diperoleh koefisien korelasi sebesar 0,718 setelah dilakukan pengujian dengan menggunakan program SPSS terbukti bahwa koefisien korelasi tersebut signifikan. Hal ini berarti bahwa terdapat pengaruh variabel bebas X1 (kecerdasan intelektual) dan X2 (motivasi belajar) secara bersama-sama terhadap variabel terikat Y (hasil belajar matematika)

Dari pengujian signifikansi koefisien regresi yang juga dilakukan dengan program SPSS diperoleh bahwa koefisien regresi tersebut signifikan yaitu ditunjukkan oleh nilai $\mathrm{Sig}=0,000<0,05$ dan $\mathrm{Fh}=47,467>\mathrm{Ft}=3,10$, dengan konstribusi kecerdasan intelektual dan motivasi belajar terhadap hasil belajar matematika sebesar 51,6 \%, sedangkan sisanya dipengaruhi oleh variabel lain. Variabel lain yang diperoleh sebesar 48,4\% merupakan faktor-faktor yang berpengaruh terhadap hasil belajar siswa yang diantaranya berasal dari faktor internal dan faktor eksternal.

\section{Kesimpulan}

Berdasarkan pembahasan yang telah diuraikan sebelumnya dapat disimpulkan bahwa: 1). Kecerdasan intelektual mempunyai pengaruh yang signifikan terhadap hasil belajar matematika siswa SD Negeri di Wilayah 3 Kelurahan Pegadungan Jakarta Barat. Hasil penelitian menunjukkan bahwa kecerdasan intelektual menyumbangkan kontribusi sebesar $11,60 \%$ terhadap hasil belajar matematika siswa. Siswa dengan kecerdasan intelektual tinggi akan memudahkan mereka dalam menerima pelajaran, karena daya nalar yang dimiliki memudahkan mereka untuk memahami soal-soal matematika sehingga hasil belajar matematika menjadi lebih baik. 2). Motivasi belajar mempunyai pengaruh yang signifikan terhadap hasil belajar matematika siswa SD Negeri di Wilayah 3 Kelurahan Pengadungan Jakarta Barat. Hasil penelitian menunjukkan bahwa motivasi belajar menyumbangkan kontribusi sebesar 40,03\% terhadap hasil belajar matematika siswa. Siswa yang memiliki motivasi belajar tinggi akan bergerak, tekun dan terus fokus terhadap tujuannya. Siswa dengan motivasi tinggi juga memiliki rasa keingintahuan dan haus akan ilmu pengetahuan. Guru yang mendapati siswa yang demikian akan lebih mudah dalam melakukan proses belajar mengajar sehingga tujuan pembelajaran dapat lebih mudah tercapai. 3). Kecerdasan intelektual dan motivasi belajar mempunyai pengaruh yang signifikan terhadap hasil belajar Matematika siswa SD Negeri di Wilayah 3 Kelurahan Pegadungan Jakarta Barat. Hasil penelitian menunjukkan bahwa kecerdasan intelektual dan motivasi belajar menyumbangkan kontribusi sebesar 51,6\% terhadap hasil belajar matematika siswa. Siswa yang memiliki kecerdasan intelektual dan motivasi yang tinggi akan mempengaruhi hasil belajar matematika siswa begitu pula sebaliknya. Sementara 48,4\% hasil belajar matematika dipengaruhi oleh faktor lain seperti kecerdasan emosional, 
The Influence of Intellectual Intelligence and Learning Motivation Against Student's Mathematics Learning Outcomes In Region 3 Kelurahan Pegadungan Jakarta Barat

media pembelajaran atau alat peraga dan model pembelajaarn yang digunakan guru ketika menyampaikan materi pelajaran kepada siswa.

\section{BIBLIOGRAFI}

Azwar, Saifuddin. (2008). Pengantar Psikologi Intelegensi, cet. 6. Yogyakarta: Pustaka Pelajar. Google Scholar

Abdurrahman, Mulyono. 2003. Pendidikan bagi anak berkesulitan belajar. Jakarta: Rineka Cipta Google Scholar

Andartari, Susanti, Santi., \& Andriani, Vidia. 2013. Pengaruh kemampuan intelektual (IQ) dan motivasi belajar terhadap hasil belajar siswa pada mata pelajaran aku. Journal Mimbar PGSD Universitas Pendidikan Ganesha, 2(1). Google Scholar

Dimyati, Mudjiono. (2013). Belajar \& pembelajaran. Jakarta: Rineka Cipta. Google Scholar

Nashar, Drs. (2004). Peranan Motivasi dan Kemampuan awal dalam kegiatan Pembelajaran. Jakarta: Delia Press. Google Scholar

Purwanto, M. Ngalim. (2017). Psikologi Pendidikan. Bandung: Remaja Rosdakarya. Google Scholar

Sadiman, Arief S. (2009). Media Pendidikan pengertian, pengembangan dan pemanfaatannya. Google Scholar

Sadulloh, Uyoh. (2010). dkk, Pedagogik (Ilmu Mendidik), Bandung: CV. Alfabeta. Google Scholar

Sagala, Syaiful. (2013). Manajemen strategik dalam peningkatan mutu pendidikan: pembuka ruang krativitas, inovasi dan pemberdayaan potensi sekolah dalam sistem otonomi sekolah. Google Scholar

Slameto, Slameto. (2015). Pembelajaran berbasis riset mewujudkan pembelajaran yang inspiratif. Satya Widya, 31(2), 102-112. Google Scholar

Sudjana, Nana. (2002). Cara Belajar Murid Aktif. Bandung: Sinar Baru Algenso. Google Scholar

Suriasumantri, Jujun S. (2007). Filsafat ilmu. Jakarta: Pustaka Sinar Harapan. Google Scholar

Yani, Fitri. (2012). Pengaruh kecerdasan intelektual, kecerdasan emosional, dan kecerdasan spiritual terhadap pemahaman akuntansi. Google Scholar 
Dwi Ningrum Handarini, Karta Sasmita, Ika Lestari

Copyright holder:

Dwi Ningrum Handarini, Karta Sasmita, Ika Lestari (2021)

First publication right:

Syntax Literate: Jurnal Ilmiah Indonesia

This article is licensed under:

(c) (i) (?) 